Review

\title{
Recent advances on natriuretic peptide system: New promising therapeutic targets for the treatment of heart failure
}

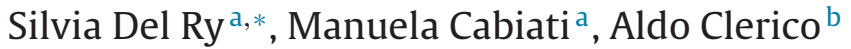 \\ a CNR Institute of Clinical Physiology, Laboratory of Cardiovascular Biochemistry, Pisa, Italy \\ b Scuola Superiore Sant'Anna and Department of Laboratory Medicine, Fondazione G. Monasterio CNR-Regione Toscana, Pisa, Italy
}

\section{A R T I C L E I N F O}

\section{Article history:}

Received 27 June 2013

Received in revised form 31 July 2013

Accepted 16 August 2013

\section{Keywords:}

Natriuretic peptides

Cardiac endocrine function

BNP

CNP

Heart failure

\begin{abstract}
A B S T R A C T
Since the discovery of the influence of the endocrine system on cardiac endocrine function 30 years ago, an increasing number of experimental and clinical studies have consolidated endocrine function of human heart as being a relevant component of a complex network including endocrine, nervous and immune systems. Many aspects, however, still remain unclear as to the production, secretion and peripheral degradation pathways of B- and C-type natriuretic peptides. In particular, the hypothesis that the circulating plasma pool of the pro-hormone can function as precursor of the active peptide hormone is yet to be fully demonstrated. According to recent studies, peripheral processing of circulating pro-hormone likely undergoes regulation pathways which seem to be impaired in patients with heart failure. This would open new perspectives also in the treatment of heart failure, and identify novel pharmacological targets for drugs inducing and/or modulating the maturation of the pro-hormone into active hormone.
\end{abstract}

(c) 2013 Elsevier Ltd. All rights reserved.

\section{Contents}

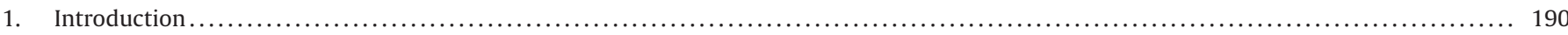

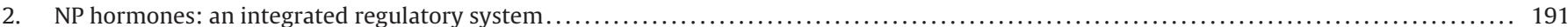

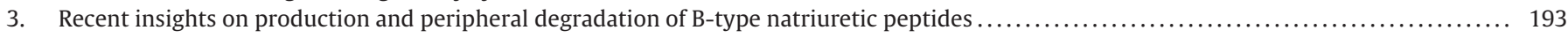

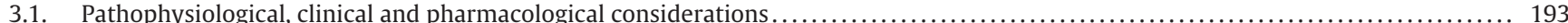

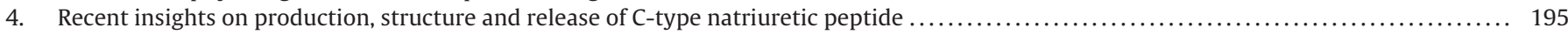

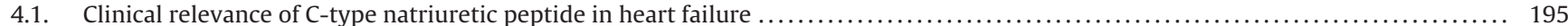

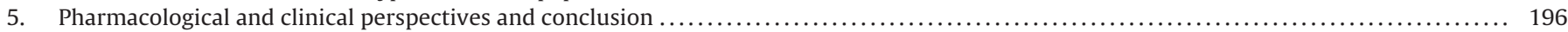

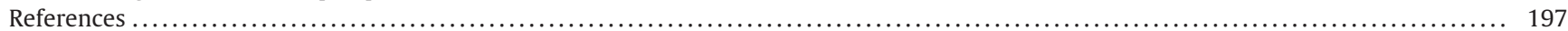

\section{Introduction}

The cardiac endocrine function was first discovered 30 years ago [1,2]. Since then, an increasing number of experimental and clinical studies have been performed on the topic, and a recent search on this field the key words "cardiac natriuretic peptides" on PubMed performed in May 2013 produced over 13,900 results, (last access May 2013). Overall, many advances have been made in the field, consolidating the endocrine function of human heart as being a relevant component of a complex network including

\footnotetext{
* Corresponding author at: Laboratory of Cardiovascular Biochemistry, Institute of Clinical Physiology - National Research Council, Via Giuseppe Moruzzi 1, 56124 Pisa, Italy. Tel.: +39050 3152793; fax: +39050 3152166 .

E-mail address: delry@ifc.cnr.it (S. Del Ry).
}

endocrine, nervous and immune systems. Yet, many key aspects have remained unsolved.

The first real breakthrough in research dates back to 1981 when de Bold et al. [1] reported intravenous injection of atrial extracts promoting a rapid and massive diuresis and natriuresis in rats. Following that seminal study, a family of natriuretic and vasodilator peptides was soon isolated, purified and within a few years was chemically identified in human tissues [3-5]. To date, research has identified, within this family of peptides, a number of different components: the atrial natriuretic peptide (ANP) and the brain (or B-type) natriuretic peptide (BNP), predominantly produced by cardiomyocytes; the C-type natriuretic peptide (CNP) predominantly produced by the endothelium; and urodilatin produced by renal tubular cells by the same gene of ANP, and which is found only in urine [3-5]. Most recently, a new peptide. named Dendroaspis natriuretic peptide (DNP) has been identified 
Table 1

Some common clinical conditions characterized by altered plasma BNP circulating levels, compared to healthy subjects.

\begin{tabular}{ll}
\hline Diseases & BNP levels \\
\hline $\begin{array}{l}\text { (A) Cardiac disease } \\
\text { Heart failure }\end{array}$ & Greatly increased \\
Acute myocardial infarction (first 2-5 days) & Greatly increased \\
Left ventricular hypertrophy with fibrosis & Increased \\
Cardiac ischemia/hypoxia & Increased \\
(B) Pulmonary disease & \\
Acute dyspnea & Increased \\
Pulmonary embolism & Increased \\
Obstructive pulmonary disease & Increased \\
(C) Endocrine disease & \\
Hyperthyroidism & Increased \\
Hyporthyroidism & Increased \\
Cushing's syndrome & Increased \\
Primary hyperaldosteronism & Increased \\
(D) Liver cirrhosis with ascites & Increased \\
(E) Renal failure (acute or chronic) & Greatly increased \\
(F) Paraneoplastic syndrome & Normal or increased \\
(G) Subarachnoid hemorrhage & Increased \\
(H) Use of cardiotoxic drugs & Increased \\
(I) Acute sepsis & Increased \\
(J) Chronic inflammatory disease (cardiac & Increased \\
impairment) & \\
\hline
\end{tabular}

in mammalian plasma, but its pathophysiological relevance in humans is still unclear [6].

All natriuretic peptides (NP) share a direct diuretic, natriuretic and vasodilator effects and an inhibitory and protective action on inflammatory processes of the myocardium, the endothelium and of smooth muscle cells, thus modulating coagulation and fibrinolysis pathways, and inhibiting platelet activation [5-10].

A conspicuous number of experimental and clinical studies demonstrated that production and secretion of NP are closely and subtly regulated by mechanical, chemical, neuro-hormonal and immunological factors $[1,3]$. Plasma concentration of NP can be considered as a sensitive index of the perturbation of the homeostatic systems regulating cardiac function and cardiovascular hemodynamics [3]. Given the important roles of the BNP in both cardiovascular physiology and pathology, it is not surprising that plasma BNP levels are increased in both cardiovascular and extra-cardiovascular diseases (Table 1).

The clinical interest on the NP system has enormously increased after several meta-analyses and international guidelines recommended measuring specific B-type-related natriuretic peptides for diagnosis, risk stratification, and follow-up of patients with heart failure [11-18]. Recent studies, however, are revealing that many Btype natriuretic peptides measured in patients with cardiovascular disease actually lack biological activity [2,5]. It appears rather that plasma of patients with heart failure carries instead large amounts of its pro-hormone peptide (i.e., proBNP) [19-28] suggesting a possible pathophysiological role of circulating proBNP levels in such patients $[2,5,29,30]$. In particular, some authors have hypothesized that the peripheral processing of circulating proBNP may be subject to some regulatory process that is impaired in patients with heart failure. If this were to be confirmed, it would obviously set new perspectives in the pharmacological treatment of heart failure $[2,5,29,30]$.

At the same time, recent studies suggest that CNP and its specific receptor, NPR-B, may play a very important role in regulating cardiac hypertrophy and remodeling in patients with systemic arterial hypertension, heart failure, and acute myocardial infarction $[31,32]$. The pathophysiological role of CNP on cardiovascular disease provides a rationale for the therapeutic potential of pharmacological interventions targeted also to CNP system [33].

Here, we will review in detail some recent and still debated findings regarding the role of NP system on cardiovascular diseases.
Table 2

Biological factors suggested to stimulate or inhibit the production/secretion of ANP and BNP in vivo or in cell culture of cardiomyocytes (modified from Ref. [2,3,5]).

\begin{tabular}{|c|c|}
\hline Suggested factors & $\begin{array}{l}\text { Suggested mean intra-cellular } \\
\text { signaling mechanism }\end{array}$ \\
\hline \multicolumn{2}{|l|}{ Stimulating } \\
\hline Mechanical strain & $\begin{array}{l}\text { Transcription factor NF-kB } \\
\text { activated by p38 MAPK }\end{array}$ \\
\hline Angiotensin II & $\begin{array}{l}\text { Transcription factor NF-kB } \\
\text { activated by p } 38 \text { MAPK }\end{array}$ \\
\hline Endothelin-1 & $\begin{array}{l}\text { Transcription factor NF-kB } \\
\text { activated by p } 38 \text { MAPK }\end{array}$ \\
\hline$\alpha$-Adrenergic agents & $\begin{array}{l}\text { Transcription factor NF-kB } \\
\text { activated by p } 38 \text { MAPK }\end{array}$ \\
\hline Arginine vasopressin & $\mathrm{Ca}^{2+}$ influx and PKC \\
\hline Cytokines (including IL-1, IL-6, TNF- $\alpha$ ) & $\begin{array}{l}\text { Transcription factor NF-kB } \\
\text { activated by p38 MAPK }\end{array}$ \\
\hline Growth factors (such as bFGF) & MAPK \\
\hline Prostaglandins (such as PGF2 $\alpha$ and PGD2) & $\begin{array}{l}\text { PLC, IP3, PKC, and MLCK } \\
\text { pathway }\end{array}$ \\
\hline Lipolysaccharide (LPS) & $\begin{array}{l}\text { Transcription factor NF-kB } \\
\text { activated by p } 38 \text { MAPK }\end{array}$ \\
\hline Chromogranin B & $\begin{array}{l}\text { Transcription factor NF-kB and } \\
\text { IP3 } / \mathrm{Ca}^{2+} \text { influx }\end{array}$ \\
\hline Thyroid hormones & $\begin{array}{l}\text { Thyroid hormone regulatory } \\
\text { element }\end{array}$ \\
\hline Corticosteroids & $\begin{array}{l}\text { Glucocorticoid responsive } \\
\text { element }\end{array}$ \\
\hline Estrogens & Not yet determined \\
\hline \multicolumn{2}{|l|}{ Inhibiting } \\
\hline Androgens & Not yet determined \\
\hline Nitric oxide (NO) & Transcription factor JMJ \\
\hline
\end{tabular}

bFGF: basic fibroblastic growth factor; IGF: insulin-like growth factor, IL: interleukin; IP3: inositol 3-phosphate; JMJ: jumonji domain-containing protein; MLCK: myosin light chain kinase; MAPK: mitogen activated protein kinase; PG: prostaglandin; PKC: protein kinase C; PLC: phospholipase C; TNF: tumor necrosis factor- $\alpha$.

First we will consider (i) the recent evidence on the altered BNP production and peripheral metabolism in patients with cardiac disease, and then (ii) the recent studies concerning the role of the CNP system on cardiovascular disease. These findings will be then (iii) set into context through a comprehensive vision on the role of endocrine cardiac function and of the network of NP hormones; and (iv) considered for their clinical and pharmacological implications.

\section{NP hormones: an integrated regulatory system}

NP hormones constitute a well-integrated regulatory system and share a similar structural conformation; they are characterized by a peptide ring with a cysteine bridge, which is well preserved throughout the phylogenetic evolution, being the portion of the peptide chain that binds to the specific receptor (Fig. 1). Members of the NP family are present in both plant and animal kingdoms [34-38]. In particular, CNP is the ancestral precursor of the NP family and is the most structurally conserved (Fig. 1) [34,37]; it is quite probable that tandem duplication of an ancestral CNP gene early in animal evolution (probably in fish) then originated ANP and BNP [39]. Indeed, considering the role of NP in fundamental biological functions, such as the regulation of solute and fluid homeostasis and cardiovascular function, the NP system must have appeared early in phylogenesis, potentiating its biological action through multiple tandem duplications of specific genes throughout the evolution of vertebrates.

Overall, the production of ANP, BNP and CNP is regulated by similar (at least in part) intracellular pathways (Fig. 2 and Table 2). Both ANP and BNP genes are regulated by the same transcriptional factors, including p38 mitogen-activated protein kinase (MAPK) [3,5]. In particular, p38 MAPK activates the transcription factor NF-kB and subsequently transcription of the ANP and BNP genes [3,5]. Putative 


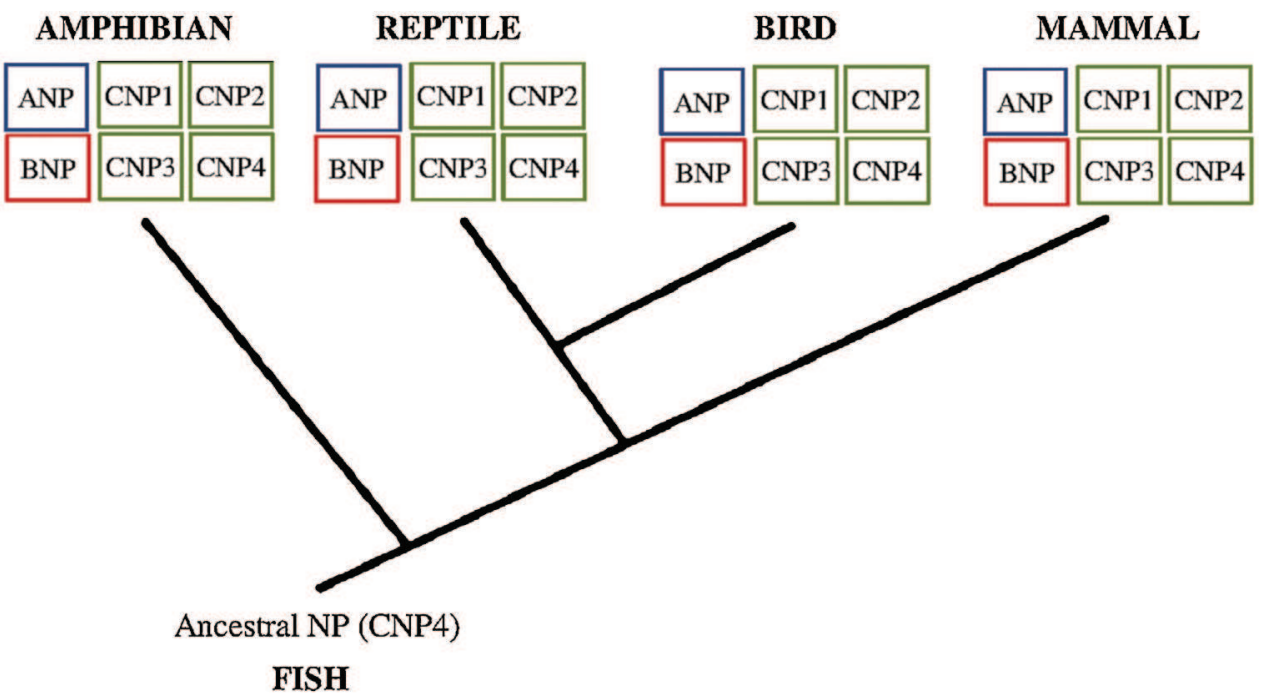

Fig. 1. Natriuretic peptide ancestral gene evolution from amphibian to mammals (modified by Ref. [34]).

biological factors regulating the production/secretion of ANP and BNP in vivo or in cell culture of cardiomyocytes are summarized in Table 2. The same transcriptional factors and neuro-endocrine effectors are likely to also regulate CNP production in several tissues [40-43].

Similarities also concern the action of ANP, BNP and CNP: they activate 3 specific components of the guanylyl cyclase receptor family that catalyze the conversion of guanosine triphosphate to cyclic guanosine monophosphate (cGMP) and pyrophosphate $[4,44]$ (Fig. 2). Intracellular cyclic GMP is the second messenger of the guanylyl cyclase receptor family that modulates several important functions in mammals: platelet aggregation, neurotransmission, sexual arousal, gut peristalsis, blood pressure, long bone growth, intestinal fluid secretion, lipolysis, cardiac hypertrophy and oocyte maturation $[4,44]$. ANP, BNP and CNP can bind and activate all the 3 guanylyl cyclase receptors, although with different specificity (Figs. 2 and 3). As a result, the NP hormones share a similar spectrum of biological actions, although there are some differences in biological potency among ANP, BNP and CNP.

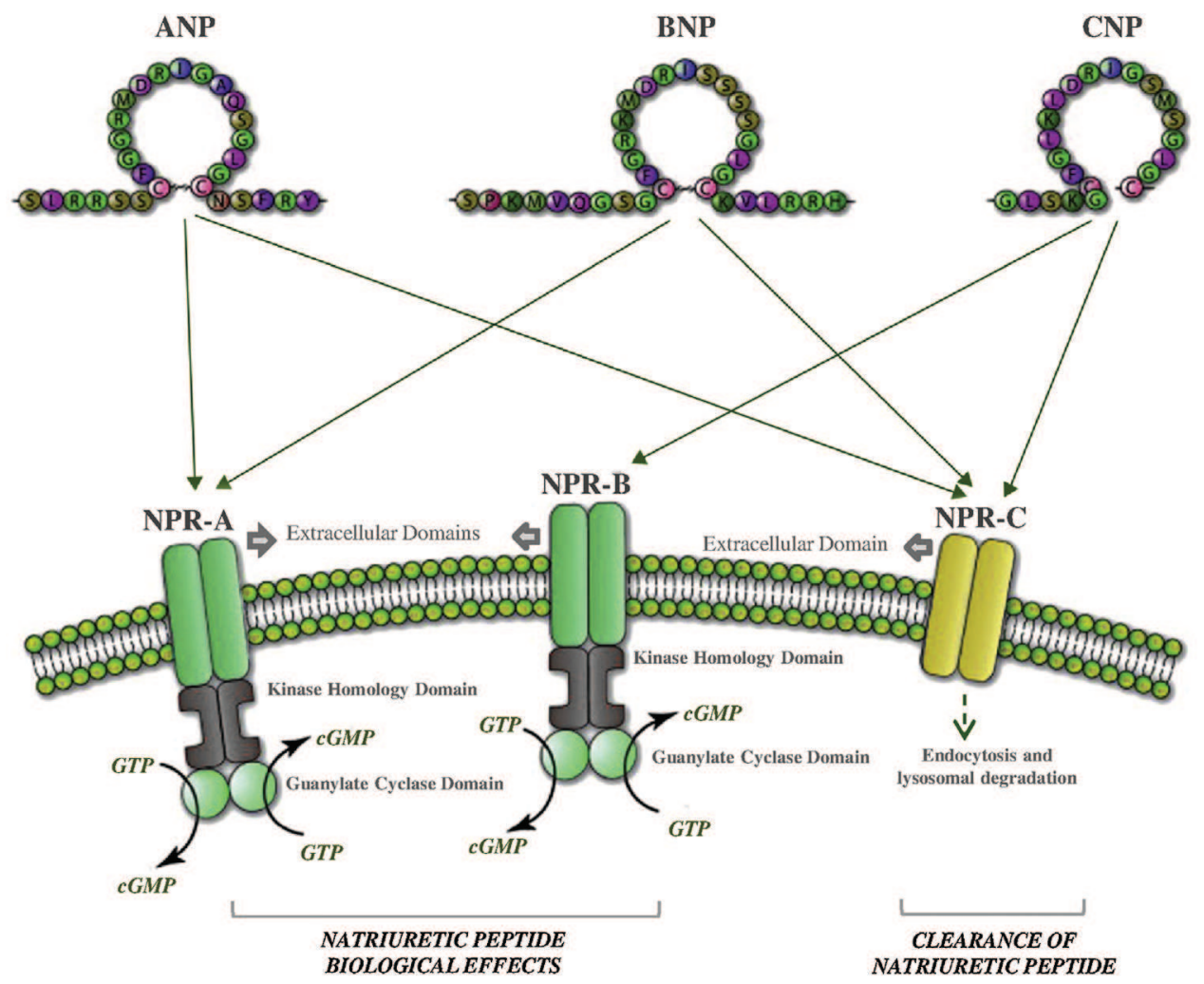

Fig. 2. Interaction of ANP, BNP, and CNP with their specific receptor NPR-A (NPR-1, GC-A) NPR-B (NPR-2, GC-B) and NPR-C (NPR-3). NPR-A and NPR-B are trans-membrane containing an equally large intracellular domain consisting of a kinase homology domain, dimerization domain, and carboxyl-terminal guanylyl cyclase domain. Differently, NPR-C only contains an intracellular domain and lacks guanylyl cyclase activity. 


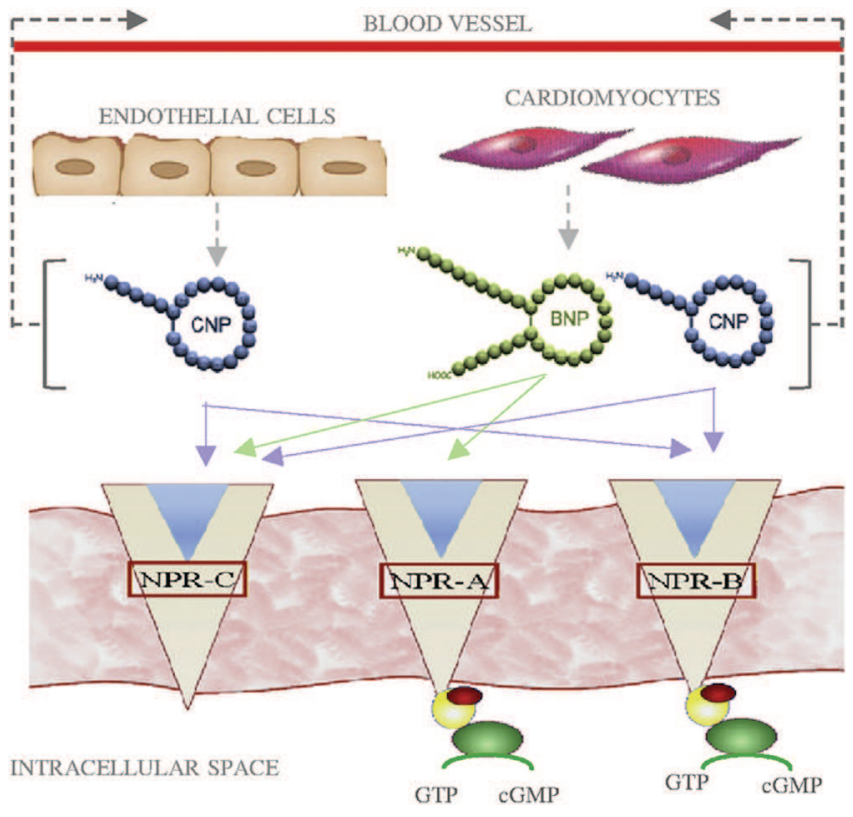

Fig. 3. Schematic model of the structure of the natriuretic peptide receptor subtypes (NPR-A/GC-A; NPR-B/GC-B and NPR-C) and natriuretic peptides presence in endothelial cells and cardiomyocytes before being released into blood vessels.

\section{Recent insights on production and peripheral degradation of $B$-type natriuretic peptides}

In human cardiomyocytes, BNP is synthesized as a 134-amino acid precursor peptide (preproBNP) and is subsequently processed to form a 108-amino acid propeptide (proBNP). Part of proBNP is $O$-glycosylated within the Golgi apparatus [5,45-48] and is secreted into the circulation, whereas a remaining part that is not $\mathrm{O}$-glycosylated may undergo enzymatic cleavage by cardiomyocyte protein convertases (such as corin and furin) to form the 76-amino acid N-terminal peptide (i.e., NT-proBNP) and the biologically active 32 -amino acid C-terminal peptide (i.e., BNP) (Fig. 4) [5]. A smaller part of intact pro-hormone is nor glycosylated or cleaved, and can be found into circulation in its intact form as proBNP. Glycosylation on the threonyl residue in position 71 ( $\mathrm{Thr} 71$ ) may regulate pro-hormone cleavage by either blocking or guiding endoproteolytic enzymes [5,48].

Recent studies indicate that the prevalent circulating form of B-type natriuretic peptides is not, however, the biologically active peptide BNP. Indeed, chromatographic procedures on plasma of experimental animals and patients with heart failure evidence a large number of circulating proBNP-derived fragments $[5,23,24,28,48-50]$. Moreover, plasma proBNP and NT-proBNP (and probably also other shorter peptides derived from these peptides) are found in both glycosylated and non-glycosylated form (especially in patients with heart failure) $[5,24,25]$. Some studies suggest that proBNP may be the major B-type NP immunoreactive form in the human blood, especially in patients with congestive heart failure [22-24,28]. In particular, Seferian et al. [46] have recently reported that the plasma pool of endogenous NT-proBNP contains a small portion (about 5\%) of nonglycosylated or incompletely glycosylated protein.

\subsection{Pathophysiological, clinical and pharmacological considerations}

Compared to NT-proBNP and proBNP, the active peptide BNP has a shorter plasma half-life (about 15-20 min vs 1 or more hours) and is present in plasma at lower concentration, especially in patients with heart failure (Table 3 and Fig. 5). Indeed, a 50-fold progressive increase in median BNP level and a 150-fold increase in median
B-type natriuretic peptide (BNP, NPPB): 3 exons, 2 introns
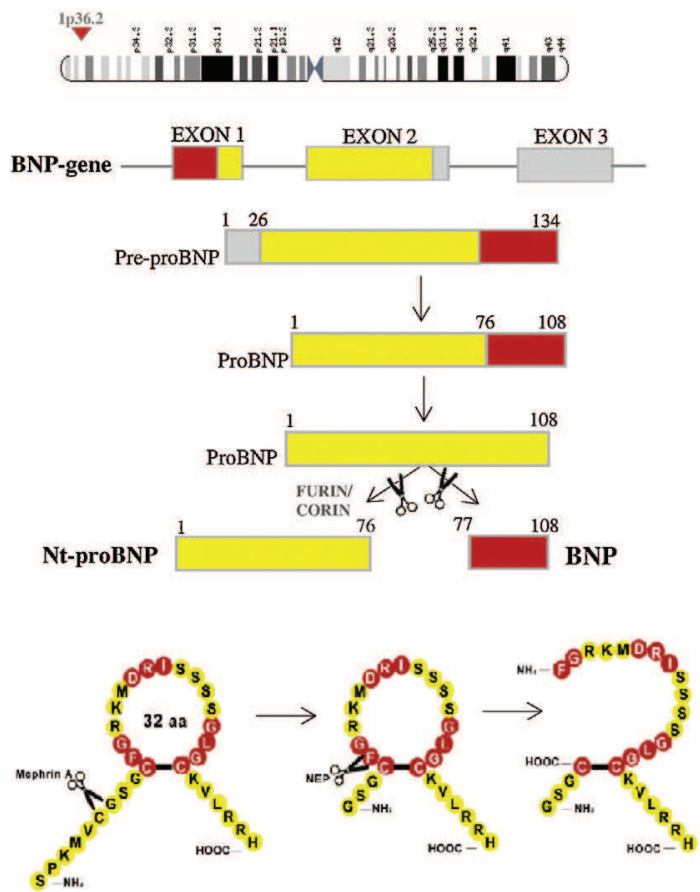

C-type natriuretic peptide (CNP, NPPC): 2 exons, 1 intron
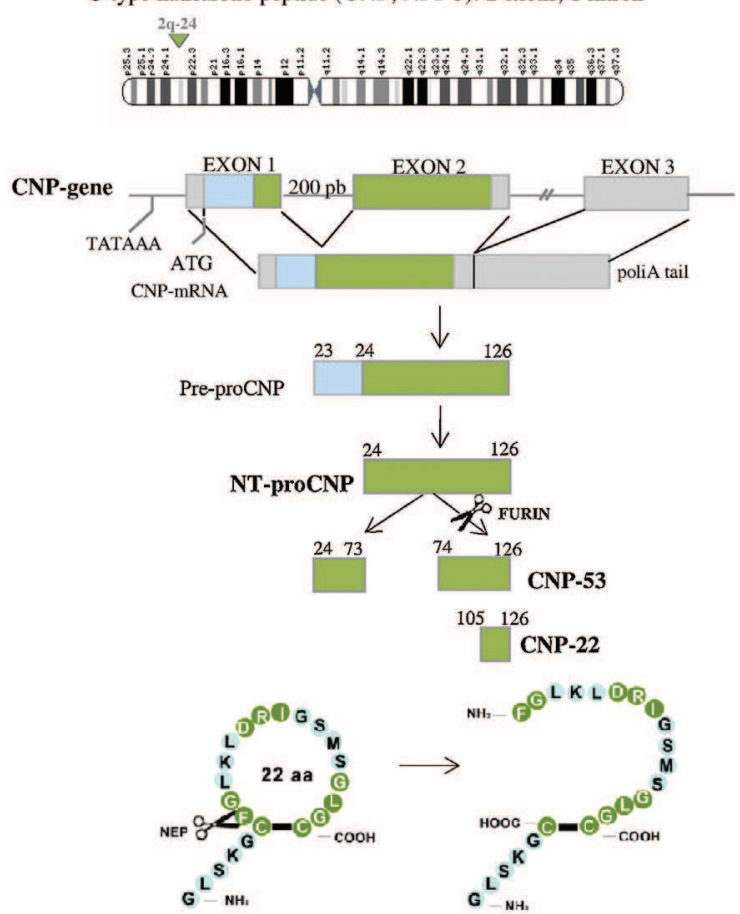

Fig. 4. Natriuretic peptide gene name, chromosome localization, processing, structure and expression. The final amino acid sequence and structure of the mature peptides along with the major degradation product are shown on the bottom. The sites of cleavage are indicated with scissors. BNP, and CNP are mainly expressed in the indicated tissues as pre-pro-hormones. The signal sequences are cleaved to form pro-BNP and pro-CNP. The peptides are further proteolytically processed to form mature peptides (modified from Ref. [4]). 
Table 3

Biochemical and physiological characteristics of BNP, NT-proBNP and proBNP peptides.

\begin{tabular}{llll}
\hline & BNP & NT-proBNP & proBNP \\
\hline Molecular mass & $3462 \mathrm{Da}$ & $8457 \mathrm{Da}^{*}$ & 76 \\
Amino acids & 32 & Inactive & 108 \\
Biological function & Active hormone & $>60$ min & Pro-hormone \\
Half life & $15-20$ min & Highly glycosylated in vivo & $>60$ min \\
Glycosylation & Not glycosylated & $4-200$ ng/L & Highly gllycosylated in vivo \\
Normal range & $1-50 \mathrm{ng} / \mathrm{L}$ & $40-100$ ng/L & \\
\hline
\end{tabular}

* The molecular mass (MM) of NT-proBNP and proBNP depends to the degree of glycosylation of the peptide; in the table are reported the MM of not glycosylated peptides.

** The range values of plasma BNP, NT-proBNP and proBNP concentrations in healthy subjects are strongly dependent to the immunoassay methods used for the measurement, as well as to age, gender and BMI values $[12,22,30,45]$. Therefore, the values reported in the table should be considered only as indicative.
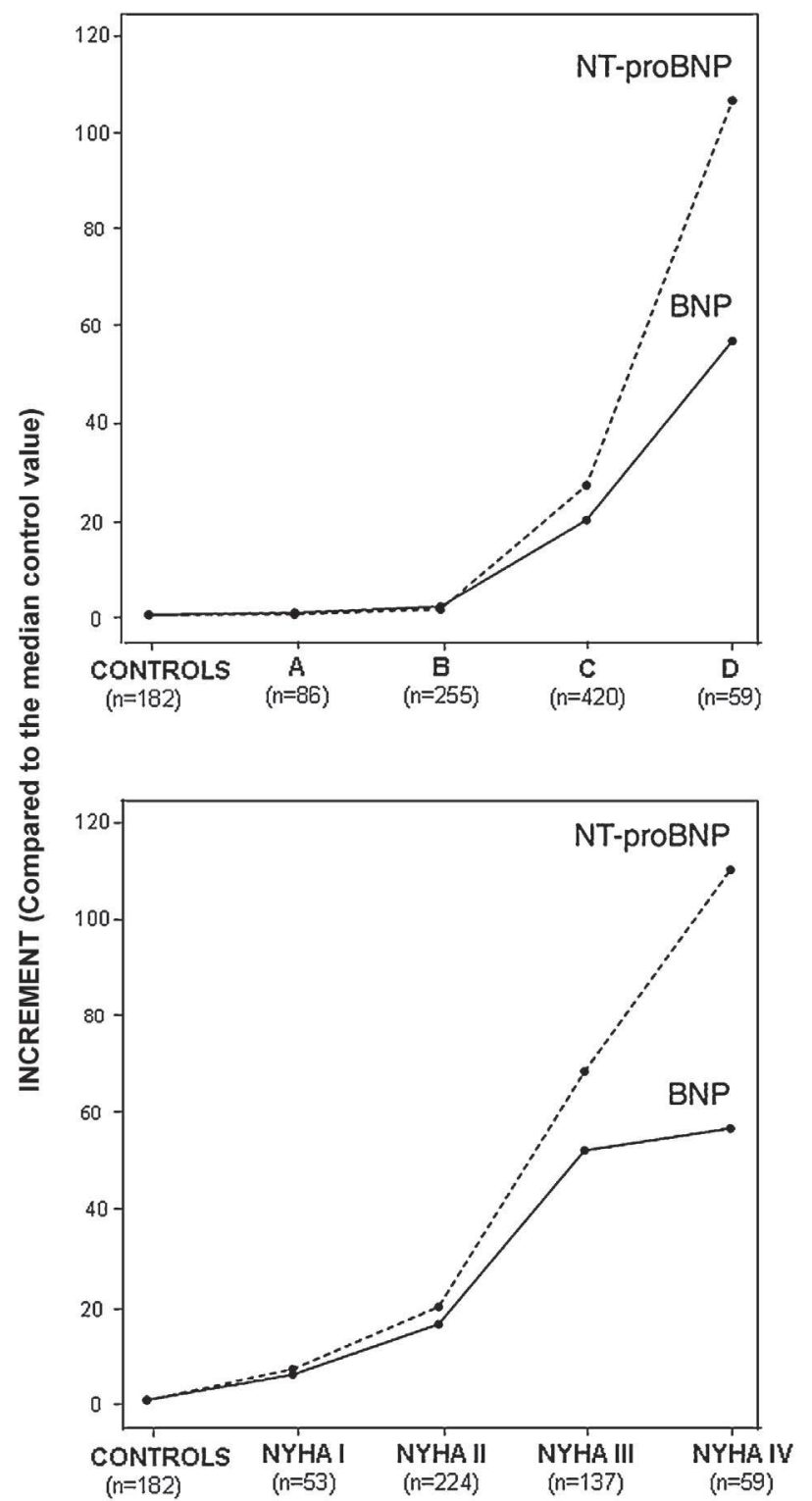

Fig. 5. BNP and NT-proBNP levels in healthy subjects and patients with different clinical severity of heart failure. Top panel: plasma BNP and NT-proBNP increment of median level in 820 patients with stage A-D of heart failure, as compared to 182 healthy subjects median concentration. Bottom panel: plasma BNP and NTproBNP increment of median level in 479 stage $C$ and $D$ patients grouped according to NYHA class, as compared to 182 healthy subjects median concentration. The data reported in the figure clearly demonstrate that patients with heart failure show higher levels of the inactive NT-proBNP than the biologically active hormone BNP. Moreover, these data indicate that both plasma BNP and NT-proBNP levels progressively increase according to the severity of heart failure. Data from our laboratory (modified from Refs. [51,52]).
NT-proBNP level are observed from healthy subjects to patients with heart failure in NYHA class IV/stage D (Fig. 5) [51]. Data reported in Fig. 5 indicate that asymptomatic patients in stage $B$ (i.e., symptomatic patients at risk for developing heart failure with structural cardiac involvement) [18], on average, have higher BNP and NT-proBNP levels than apparently healthy subjects. Furthermore, symptomatic patients with moderate systolic heart failure, such as those in class NYHA class I, show also significantly higher levels of NP than apparently healthy subjects (Fig. 5). These findings represent the rationale for evaluating the diagnostic accuracy of BNP and NT-proBNP levels in screening programs including general population or primary care patients [51,52]. Moreover, some recent studies reported that patient with heart failure have also greatly increased circulating proBNP levels compared to healthy subjects [22,26-28]. From a pathophysiological point of view, a blunted natriuretic response after pharmacological doses of ANP and BNP has been observed in experimental models and in patients with chronic heart failure, suggesting a resistance to the biological effects of NP, mainly to natriuresis [3]. As mentioned above [3], resistance to the biological action of NP can be attributed to at least three kinds of different causes/mechanisms, acting at pre-receptor, receptor, and post-receptor level, respectively.

Based on recent findings [19-28,49,50,53-55], resistance at the pre-receptor level in patients with heart failure could be explained by an insufficient post-translation maturation of the biosynthetic precursors of B-type natriuretic peptide system. Accordingly, it is theoretically conceivable that the active hormone (i.e., BNP) could be produced even in vivo from the circulating precursor proBNP $_{1-108}$ by plasma enzyme degradation [19-28,49,50,53-55]. Indeed, the soluble form of corin, a transmembrane serine protease able to cleave proBNP, is also capable of processing the circulating intact precursor of natriuretic hormones [53,54]. Dong et al. [54] recently confirmed that soluble corin is detectable in human blood. Furthermore, these authors report that levels of plasma corin are significantly lower in patients with heart failure than in healthy controls, and that the reduction in plasma enzyme is correlated to the severity of the disease [54]. Finally, Semenov et al. demonstrated that synthetic or recombinant human proBNP can be processed to active BNP in the circulating blood, when injected in the femoral vein of rats [55]. On the other hand recent results indicate that proBNP may bind and also activate the specific receptor of NP (i.e., the guanylyl cyclase-A, also named NPR-A), although with reduced efficacy compared to ANP and BNP [56]. As a result, proBNP should be considered to be a low efficacy agonist compared to biologically active hormone BNP, in this way contributing to the reduced NP response in patients with heart failure. Indeed, reduced degradation of proBNP may contribute to the increased proBNP:BNP ratio observed in patients with congestive heart failure, consequently explaining (almost in part) the peripheral resistance to biological action of NP [57].

Peripheral processing of circulating proBNP seems to be submitted to regulatory rules that are impaired in patients with heart failure. If this were to be confirmed, such hypothesis would 

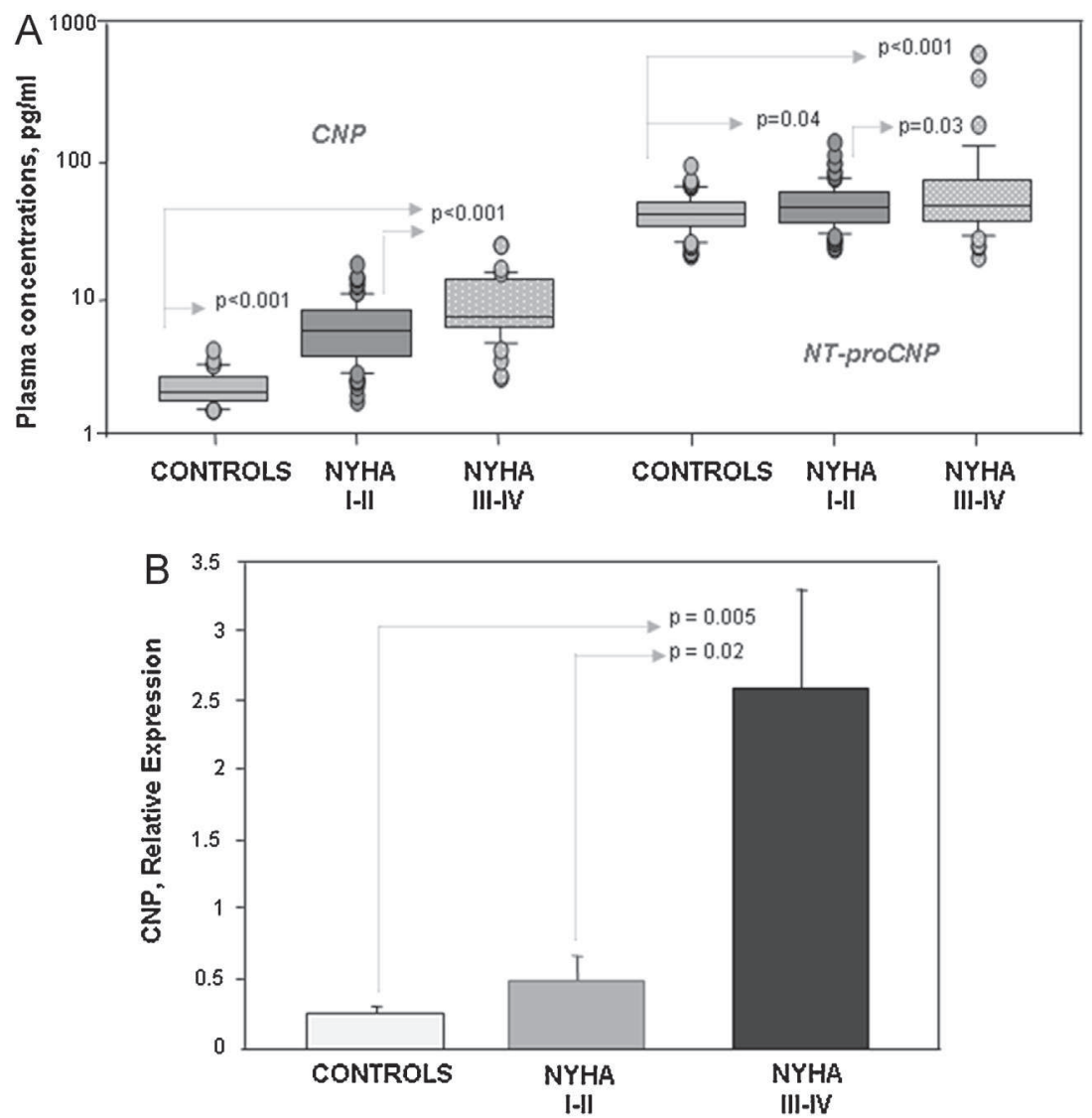

Fig. 6. (a) Distribution of CNP and NT-pro-CNP plasma levels in chronic heart failure patients as a function of disease severity. Each box consists of 5 horizontal lines displaying the 10th, 25th, 50th (median), 75th, and 90th percentiles of the variable. All values above the 90th percentile and below the 10 th percentile are plotted separately (modified by Ref. [76]). (b) CNP mRNA expression measured by Real Time PCR in human whole blood of HF patients as a function of clinical severity (modified by Ref. [90]).

open new perspectives even in the treatment of heart failure $[2,20,21,29,30,58]$, and could identify novel pharmacological targets for drugs inducing and/or modulating the maturation of the prohormone into active hormone (i.e., BNP) [2,29,58]. In conclusion, these studies, taken together, strongly indicate that the prevalent amount of the circulating B-type natriuretic peptides in patients with heart failure lacks biological activity. These results open the question about the possible regulation of the peripheral processing of circulating proBNP. Based on this hypothesis, several authors suggested the biologically active BNP can be produced also in blood from proBNP plasma pool. Accordingly, plasma proBNP should be considered to be also a circulating precursor of the biologically active hormone, BNP $[2,5,20,25,30,58]$. In other words, BNP may be produced from the precursor proBNP in both cardiomyocytes and blood.

\section{Recent insights on production, structure and release of C-type natriuretic peptide}

First isolated from porcine brain in 1990 [59] CNP, is the most expressed natriuretic peptide in the brain; it is also widely expressed throughout the vasculature and is found in particularly high concentrations in the endothelium, where it plays a role in the local regulation of vascular tone [60-62]. It is stored inside endothelial cells and is able to induce vasorelaxation by hyperpolarization, suggesting that CNP may be an endothelium-derived hyperpolarizing factor (EDHF), participating in the paracrine action of other endothelial vasorelaxant mediators, such as nitric oxide (NO) and prostacyclin [63-65]. Recently, CNP expression was also found in cardiomyocytes at both gene and protein levels [66]. The human gene encoding for CNP, NPPC (GeneID 4880), is located on chromosome 2 and encodes a polypeptide of 126 amino acids, with a 23 amino acid signal sequence followed by a 103 amino acid proCNP $[67,68]$. PreproCNP shows remarkable homology between species and the circulating 22 amino acid carboxyl terminal form is absolutely identical in chimpanzees, dogs, mice, and rats species [68] (Fig. 1).

Processing of proCNP to its mature form may occur through the action of the intracellular serine endoprotease, furin. In vitro, furin cleaves the 103 amino acid proCNP into a 53 amino acid carboxylterminal biologically active peptide (CNP-53), that is the major active form of CNP at tissue level [69,70] (Fig. 4). In the systemic circulation, a shorter 22 amino acid form dominates (CNP-22) but the protease responsible for this cleavage is not known. Importantly, CNP-53 and CNP-22 appear to bind and activate their specific receptor, NPR-B, equally well $[70,71]$. CNP is not stored in granules and its secretion is increased by growth factors $[72,73]$ and shear stress [74]. The clearance of CNP-22 in human plasma is very rapid, with a calculated half-life of $2.6 \mathrm{~min}[75,76]$.

\subsection{Clinical relevance of C-type natriuretic peptide in heart} failure

The involvement of CNP in cardiovascular disease has been recently taking on an increasingly important role. Several studies carried out in humans have reported increased NT-proCNP $[77,78]$ and CNP plasma levels in patients with chronic heart failure compared to healthy subjects [77,79-83]. Data reported in Fig. 6a indicate a progressive plasma increase of both CNP and NT-proCNP in function of clinical severity. Because of (i) the 
progressive rise in CNP and NT-proCNP plasma values with the worsening of symptoms [77,79-81] and (ii) the negative relation between plasma CNP values and left ventricular ejection fraction [81], such increase in secretion appears to be related to the severity of the disease. Moreover, this increase in CNP plasma concentrations in parallel to worsening clinical severity could be a compensatory effect in response to cardiac dysfunction; together with the other natriuretic peptides ANP and BNP, CNP probably contributes to neuro-hormonal activation (which is a hallmark of chronic heart failure) counteracting the predominance of vasoconstrictor and sodium retentive systems (sympathetic, rennin-angiotensin-aldosterone, vasopressin and endothelin systems) $[81,82]$.

Recent studies indicate that the production of C-type natriuretic peptides, especially in patients with heart failure directly involves the heart and, namely, the myocardium [79,84-88]. In fact, immunohistochemistry and radioimmunoassay techniques within the myocardium demonstrate that CNP cardiac expression is two to three times higher in patients with chronic heart failure compared to controls [66]; in particular, CNP levels in patients with chronic heart failure are significantly increased in the coronary sinus, as compared to the aorta $[84,85]$.

From a pathophysiological point of view, CNP also carries out an important autocrine and paracrine function in pathophysiological cardiac remodeling $[84,85]$.

Studies carried out by bimolecular technique both in animals model $[86,88]$ that in human leukocytes $[89,90]$ permitted to detect the mRNA expression of CNP and NPR-B in normal myocardial tissue as well as in human whole blood samples of healthy subjects. The studies on minipigs have reported myocardial alterations in the expression of CNP and NPR-B in normal and failing hearts [86-88], moreover an increase of CNP and NPR-B transcriptomic profiling was observed in human whole blood samples of heart failure patients [89] and in a recent paper [90] original data relative to CNP mRNA increase as a function of clinical severity in parallel with a down-regulation of NPR-B expression in patients with worsening of symptoms was reported (Fig. 6b). Hence CNP could have a behavior similar to BNP, underlining the importance of the endocrine role of myocardium in the generation of CNP during early left ventricular dysfunction [86-88]. In particular the studies showed a CNP protein and gene expression detected in tissue of normal and failing hearts, along with an increased myocardial CNP synthesis in the presence of the NPR-B down-regulation in failing heart [86]. The presence of CNP in cardiac tissue would suggest a possible synergistic effect with the other natriuretic cardiac peptides, ANP and BNP [91]. Moreover, recent studies have found CNP expression in cardiomyocytes, both at the gene and protein levels, as well as NPR-B mRNA expression [66]. This co-localization of the peptide and its specific receptor NPR-B in cardiomyocytes suggests the heart to be actively involved in the production of CNP, reinforcing its involvement in cardiovascular pathophysiology.

Taken together, these studies indicate that CNP is produced in the heart during cardiac failure, where it may elicit important compensatory physiological consequences in ventricular remodeling. Positive effects of CNP on cardiac contractility, lusitropy and dromotropy have been also described in several studies using intact animals, isolated hearts, cardiac muscle preparations and isolated cardiomyocytes [92]. At present, however, evidence toward cardioprotective effects of CNP is controversial. Studies have reported that activation of the CNP/NPR-B pathway following myocardial infarction promotes apoptosis of cardiomyocytes [93] and mediates anti-proliferative and anti-hypertrophic effects in adult cardiac cells [32,94]; furthermore, in infarct remodeled myocardium, expression of CNP is locally increased in the presence of a dense capillary network [95]. In rats, in vivo administration of CNP improves cardiac function and attenuates cardiac remodeling after myocardial infarction. It is hypothesized that this effect on cardiac remodeling is due to CNP anti-fibrotic and anti-hypertrophic actions, which would identify this peptide as a useful novel antiremodeling pharmacological agent $[94,96]$. In addition, given the inhibitory effects of CNP on cardiac fibrosis and hypertrophy in vitro, CNP could operate against the progression of late cardiac remodeling after myocardial infarction [96].

Finally, CNP appears to also be potentially involved in the renal natriuretic peptide system, which participates in the regulation of sodium and water balance and the renal circulation [84]. In fact, in patients with heart failure also the renal CNP system is activated and urinary excretion of CNP is significantly increased [97].

\section{Pharmacological and clinical perspectives and conclusion}

Despite the remarkable advances in the knowledge on cardiac endocrine function and the NP network, which have been narrowing focus toward specific pharmacologic targets, there are still many aspects that need to be solved.

In first instance, the production, secretion and peripheral degradation pathways of both B- and C-type natriuretic peptides, still need to be confirmed, clarifying in particular the hypothesis of whether the circulating plasma pool of the pro-hormone can actually function as precursor of the active peptide hormone.

Another important unsolved question concerns the use of NP as therapeutic agents in heart failure [98-100]. Hospitalization for heart failure is a clinical entity associated with high post discharge morbidity and mortality [100,101]. Unfortunately, few therapies are available to improve outcomes in patients with this condition [100]. In the first years of the new century, the anti-fibrotic and remodeling effects of NP suggested the use of some analogs of BNP (like as Nesiritide, a recombinant human BNP) as therapeutics in heart failure [98-100]. The initial enthusiasm for the parenteral (IV infusion) administration of NP analogs was soon attenuated by the appearance of some adverse effects (such as severe hypotension) on survival and renal function [98-100]. However, a pilot study [102] has recently suggested that subcutaneous administration of BNP (instead of IV infusion) may represents a novel, safe, and efficacious protein therapeutic strategy in patients with heart failure.

Although several clinical trials have documented the benefits and risks of the use of synthetic ANP (Anaritide), BNP (Nesiritide) and urodilatin (Ularitide) in patients with cardiovascular and renal diseases $[103,104]$, to our knowledge, only few clinical studies have been reported on the use of some CNP analogs for the treatment of heart failure. An innovative approach may be to create "designer" chimeric peptides, which hold the possibility to extend both the application and therapeutic benefits possible with a natriuretic peptide based approach [105]. For example, CD-NP is a chimeric peptide consisting of CNP and part of DNP [105-107]. This peptide was shown to possess cyclic guanosine monophosphate-activating, natriuretic, and aldosterone suppressing properties without inducing excessive hypotension when given to healthy subjects [105]. This preliminary study may pave the way for further clinical trials.

The administration of some oral agents, which are able to modulate the production and/or degradation of active hormones in the circulation, may have some beneficial effects on cardiac remodeling without affecting cardiovascular hemodynamics. In particular, inhibition of the neutral endopeptidase had been investigated as a potential novel therapeutic approach because of its ability to increase the plasma concentrations of NP in combination with other cardiovascular agents, such as angiotensin-converting enzyme inhibitors, and antagonists of the angiotensin receptor [101]. These data once more underline the close link between 
the NP system and the network including endocrine, nervous and immune systems.

\section{References}

[1] de Bold AJ, Borenstein HB, Veress AT, Sonnenberg H. A rapid and potent natriuretic response to intravenous injection of atrial myocardial extract in rats. Life Sci 1981;28:89-94.

[2] Clerico A, Giannoni A, Vittorini S, Passino C. Thirty years of the heart as an endocrine organ: physiological role and clinical utility of cardiac natriuretic hormones. Am J Physiol Heart Circ Physiol 2011;301:H12-20.

[3] Clerico A, Recchia FA, Passino C, Emdin M. Cardiac endocrine function is an essential component of the homeostatic regulation network: physiological and clinical implications. Am J Physiol Heart Circ Physiol 2006;290:H17-29.

[4] Potter RL, Yoder AR, Flora DR, Antos LK, Dickey DM. Natriuretic peptides: their structures, receptors, physiologic functions and therapeutic applications. Handb Exp Pharmacol 2009;191:341-66.

[5] Goetze JP. Biosynthesis of cardiac natriuretic peptides. Results Probl Cell Differ 2010;50:97-120.

[6] Richards AM, Lainchbury JG, Nicholls MG, Cameron AV, Yandle TG. Dendroaspis natriuretic peptide: endogenous or dubious? Lancet 2002;359: $5-6$.

[7] de Bold AJ. Natriuretic peptides gene expression and secretion in inflammation. J Invest Med 2009;57:29-32.

[8] Qian JY, Haruno A, Asada Y, Nishida T, Saito Y, Matsuda T, et al. Local expression of C-type natriuretic peptide suppresses inflammation, eliminates shear stress-induced thrombosis, and prevents neointima formation through enhanced nitric oxide production in rabbit injured carotid arteries. Circ Res 2002;91:1063-9.

[9] Scotland RS, Cohen M, Foster P, Lovell M, Mathur A, Ahluwalia A, et al. C-type natriuretic peptide inhibits leukocyte recruitment and platelet-leukocyte interactions via suppression of P-selectin expression. Proc Natl Acad Sci USA 2005; 102:14452-7.

[10] Villar IC, Panayiotou CM, Sheraz A, Madhani M, Scotland RS, Nobles M, et al. Definitive role for natriuretic peptide receptor-C in mediating the vasorelaxant activity of C-type natriuretic peptide and endothelium-derived hyperpolarising factor. Cardiovasc Res 2007;74:515-25.

[11] Doust JA, Glasziou PP, Pietrzak E, Dobson AJ. A systematic review of the diagnostic accuracy of natriuretic peptides for heart failure. Arch Intern Med 2004;164:1978-84.

[12] Doust JA, Pietrzak E, Dobson A, Glasziou P. How well does B-type natriuretic peptide predict death and cardiac events in patients with heart failure: systematic review. Br Med J 2005;330(7492):625.

[13] Clerico A, Fontana M, Ripoli A, Emdin M. Clinical relevance of BNP measurement in the follow-up of patients with chronic heart failure. Adv Clin Chem 2009;48:163-9.

[14] Porapakkham P, Porapakkham P, Zimmet H, Billah B, Krum H. B-type natriuretic peptide-guided heart failure therapy: a meta-analysis. Arch Intern Med 2010;170:507-14

[15] Jessup M, Abraham WT, Casey DE, Feldman AM, Francis GS, Ganiats TG, et al. 2009 focused update: ACCF/AHA guidelines for the diagnosis and management of heart failure in adults: a report of the American College of Cardiology Foundation/American Heart Association Task Force on Practice Guidelines: developed in collaboration with the International Society for Heart and Lung Transplantation. Circulation 2009;119:1977-2016.

[16] NICE. Clinical Guideline No. 108: chronic heart failure: national clinical guideline for diagnosis and management in primary and secondary care; 2010. p. $1-222$.

[17] Thygesen K, Mair J, Mueller C, Huber K, Weber M, Plebani M, et al. Recommendations for the use of natriuretic peptides in acute cardiac care. A position statement from the Study Group on Biomarkers in Cardiology of the ESC Working Group on Acute Cardiac Care. Eur Heart J 2012;33: 2001-6.

[18] Richards AM, Troughton RW. Use of natriuretic peptides to guide and monitor heart failure therapy. Clin Chem 2012:62-71.

[19] Liang F, O’Rear J, Schellenberger U, Tai L, Tai L, Lasecki M, et al. Evidence for functional heterogeneity of circulating B-type natriuretic peptide. J Am Coll Cardiol 2007:49:1071-8.

[20] Goetze JP. Biochemistry of pro-B-type natriuretic peptide-derived peptides: the endocrine heart revisited. Clin Chem 2004;49:1503-10.

[21] Goetze JP. ProBNP-derived peptides in cardiac disease. Scand J Clin Lab Invest 2004;64:497-510.

[22] Giuliani I, Rieunier F, Larue C, Delagneau JF, Granire C, Pau B, et al. Assay for measurement of intact B-type natriuretic peptide prohormone in blood. Clin Chem 2006;52:1054-61.

[23] Seferian KR, Tamm NN, Semenov AG, Mukharyamova KS, Tolstaya AA, Koshkina EV, et al. The brain natriuretic peptide (BNP) precursor is the major immunoreactive form of BNP in patients with heart failure. Clin Chem 2007;53:866-73.

[24] Hammerer-Lercher A, Halfinger B, Sarg B, Mair J, Puschendorf B, Griesmacher A, et al. Analysis of circulating forms of proBNP and NT-proBNP in patients with severe heart failure. Clin Chem 2008;54:858-65.

[25] Goetze JP, Rehfeld JF. Peptide hormones and their prohormones as biomarkers. Biomark Med 2009;3:335-8.
[26] Dries DJ, Ky B, Wu A, Rame JE, Putt M, Cappola T. Simultaneous assessment of unprocessed ProBNP 1-108 in addition to processed BNP32 improves risk stratification in ambulatory patients with systolic heart failure. Circ Heart Fail 2010:3:220-7.

[27] Macheret F, Boerrigter G, McKie P, Costello-Boerrigter L, Lahr B, Heublein $\mathrm{D}$, et al. Pro-B-type natriuretic peptide 1-108 circulates in the general community: plasma determinants and detection of left ventricular systolic dysfunction. J Am Coll Cardiol 2011;57:1386-95.

[28] Miller WL, Phelps MA, Wood CM, Schellenberger U, van Le A, Perichon R, et al. Comparison of mass spectrometry and clinical assay measurements of circulating fragments of B-type natriuretic peptide in patients with chronic heart failure. Circ Heart Fail 2011;4:355-60.

[29] Emdin M, Passino C, Clerico A. Natriuretic peptide assays revisited: do we need pro-B-type natriuretic peptide? J Am Coll Cardiol 2011;57: 1396-8.

[30] Clerico A, Vittorini S, Passino C. Circulating forms of the B-type natriuretic peptide prohormone: pathophysiologic and clinical considerations. Adv Clin Chem 2012;58:31-44.

[31] Del Ry S. C-type natriuretic peptide: a new cardiac mediator. Peptides 2012;40:93-8

[32] Calvieri C, Rubattu S, Volpe M. Molecular mechanisms underlying cardiac antihypertrophic and antifibrotic effects o natriuretic peptides. J Mol Med 2012;90:5-13.

[33] Lumsden NG, Khambata RS, Hobbs AJ. C-type natriuretic peptide (CNP): cardiovascular roles and potential as a therapeutic target. Curr Pharm Des 2010;16:4080-8.

[34] Takei Y. Does the natriuretic peptide system exist throughout the animal and plant kingdom? Comp Biochem Physiol B 2001;129:559-73.

[35] Vesely DL, Giordano AT. Atrial natriuretic peptide hormonal system in plants. Biochem Biophys Res Commun 1991;179:695-700.

[36] Billington T, Pharmawati M, Gehring CA. Isolation and immunoaffinity purification of biologically active plant natriuretic peptide. Biochem Biophys Res Commun 1997;235:722-5.

[37] Loretz CA, Pollina C. Natriuretic peptides in fish physiology. Comp Biochem Physiol A 2000;125:169-87.

[38] Kawakoshi A, Hyodo S, Inoue K, Kobayashi Y, Takei Y, Four natriuretic peptides (ANP BNP, VNP and CNP) coexist in the sturgeon: identification of BNP in fish lineage. J Mol Endocrinol 2004;32:547-55.

[39] Inoue K, Sakamoto T, Yuge S, Iwatani H, Yamagami S, Tsutsumi M, et al. Structural and functional evolution of three cardiac natriuretic peptides. Mol Biol Evol 2005;22:2428-34.

[40] Woodard GE, Rosado JA, Brown J. Expression and control of C-type natriuretic peptide in rat vascular smooth muscle cells. Am J Physiol Regul Integr Comp Physiol 2002;282:R156-65.

[41] Tan T, Scholz PM, Weiss HR. Hypoxia inducible factor-1 improves the negative functional effects of natriuretic peptide and nitric oxide signaling in hypertrophic cardiac myocytes. Life Sci 2010;87:9-16.

[42] Ichiki T, Boerrigter G, Huntley BK, Sangaralingham SJ, McKie PM, Harty GJ, et al. Differential expression of the pro-natriuretic peptide convertases corin and furin in experimental heart failure and atrial fibrosis. Am J Physiol Regul Integr Comp Physiol 2013;304:R102-9.

[43] Osterbur K, Yu DH, de Clue AE. Interleukin-1, tumour necrosis factor-a and lipopolysaccharide induce C-type natriuretic peptide from canine aortic endothelial cells. Res Vet Sci 2013;94:478-83.

[44] Potter LR. Guanylyl cyclase structure, function and regulation. Cell Signal 2011;23:1921-6.

[45] Schellenberger U, O'Rear J, Guzzetta A, Jue RA, Protter AA, Pollitt NS. The precursor to B-type natriuretic peptide is an O-linked glycoprotein. Arch Biochem Biophys 2006;451:160-6.

[46] Seferian KR, Tamm NN, Semenov AG, Tolstaya AA, Koshkina EV, Krasnoselsky MI, et al. Immunodetection of glycosylated NT-proBNP circulating in human blood. Clin Chem 2008;54:866-73.

[47] Crimmins DL, Kao JL. A glycosylated form of the human cardiac hormone pro B-type natriuretic peptide is an intrinsically unstructured monomeric protein. Arch Biochem Biophys 2008;475:36-41.

[48] Semenov AG, Postnikov AB, Tamm NN, Seferian KR, Karpova NS, Bloshchitsyna MN, et al. Processing of pro-brain natriuretic peptide is suppressed by $O$-glycosylation in the region close to the cleavage site. Clin Chem 2009;55:489-98.

[49] Shimizu H, Masuta K, Aono K, Asada H, Sasakura K, Tamaki M, et al. Molecular forms of human brain natriuretic peptide in plasma. Clin Chim Acta 2002;316:129-35.

[50] Shimizu H, Masuta K, Asada H, Sugita K, Sairenji T. Characterization of molecular forms of probrain natriuretic peptide in human plasma. Clin Chim Acta 2003;334:233-9.

[51] Emdin M, Passino C, Prontera C, Fontana M, Poletti R, Gabutti A, et al. Comparison of brain natriuretic peptide (BNP) and amino-terminal proBNP for early diagnosis of heart failure. Clin Chem 2007;53:1264-72.

[52] Emdin M, Fontana M, Poletti R, Gabutti A, Mammini C, Rossi A, et al. Natriuretic peptide testing in primary care patients. Clin Chem Lab Med 2008;46:1533-42.

[53] Knappe S, Wu F, Masikat MR, Wu Q. Functional analysis of the transmembrane domain and activation cleavage of human corin: design and characterization of a soluble corin. J Biol Chem 2003;278:52363-70.

[54] Dong N, Chen S, Yang J, He L, Liu P, Zheng D, et al. Plasma soluble corin in patients with heart failure. Circ Heart Fail 2010;3:207-11. 
[55] Semenov AG, Seferian KR, Tamm NN, Artem'eva MM, Postnikov AB, Bereznikova AV, et al. Human pro-B-type natriuretic peptide is processed in the circulation in a rat model. Clin Chem 2011;57:883-90.

[56] Dickey DM, Potter LR. ProBNP ${ }_{1-108}$ is resistan to degradation and actvates guanylyl cyclase-A with reduced potency. Clin Chem 2011;57:1272-8.

[57] Iervasi G, Clerico A, Berti S, Pilo A, Biagini A, Bianchi R, et al. Altered tissue degradation and distribution of atrial natriuretic peptide in patients with idiopathic dilated cardiomyopathy and its relationship with clinical severity of the disease and sodium handling. Circulation 1995;91:2018-27.

[58] Clerico A, Vittorini S, Passino C. Measurement of the pro-hormone of brain type natriuretic peptide (proBNP): methodological considerations and pathophysiological relevance. Clin Chem Lab Med 2011;49:1949-54.

[59] Sudoh T, Minamino N, Kangawa K, Matsuo H. C-type natriuretic peptide (CNP): a new member of the natriuretic peptide family identified in porcine brain. Biochem Biophys Res Commun 1990;168:863-70.

[60] Abassi Z, Karram T, Ellaham S, Winaver J, Hoffman A. Implications of the natriuretic peptide system in the pathogenesis of heart failure: diagnostic and therapeutic importance. Pharm Ther 2004;102:223-41.

[61] Barr CS, Rhodes P, Struthers AD. C-type natriuretic peptide. Peptides 1996; $17: 1243$.

[62] Scotland RS, Ahluwalia A, Hobbs AJ. C-type natriuretic peptide in vascular physiology and disease. Pharm Ther 2005;105:85-93.

[63] Barton M, Beny JL, d'Uscio LV, Wyss T, Noll G, Luscher TF. Endotheliumindependent relaxation and hyperpolarization to C-type natriuretic peptide in porcine coronary arteries. J Cardiovasc Pharmacol 1998;31:377-83.

[64] Chauhan SD, Nilsson H, Ahluwalia A, Hobbs AJ. Release of C-type natriuretic peptide accounts for the biological activity of endothelium-derived hyperpolarizing factor. PNAS 2003:100:1426-31.

[65] Griffith TM. Endothelium-dependent smooth muscle hyperpolarization: do gap junctions provide a unifying hypothesis? Brit J Pharm 2004;141:881-903.

[66] Del Ry S, Cabiati M, Vozzi F, Battolla B, Caselli C, Forini F, et al. Expression of Ctype natriuretic peptide and its receptor NPR-B in cardiomyocytes. Peptides 2011;32:1713-8.

[67] Ogawa Y, Itoh H, Yoshitake Y, Inoue M, Yoshimasa T, Serikawa T, et al. Molecular cloning and chromosomal assignment of the mouse C-type natriuretic peptide (CNP) gene (Nppc): comparison with the human CNP gene (NPPC). Genomics 1994;24:383-7.

[68] Tawaragi Y, Fuchimura K, Tanaka S, Minamino N, Kangawa K, Matsuo H. Gene and precursor structures of human C-type natriuretic peptide. Biochem Biophys Res Commun 1991;175:645-51.

[69] Wu C, Wu F, Pan J, Morser J, Wu Q. Furin-mediated processing of Pro-C-type natriuretic peptide. J Biol Chem 2003;278:25847-52.

[70] Brown J, Chen Q Hong G. An autocrine system for C-type natriuretic peptide within rat carotid neointima during arterial repair. Am J Physiol 1997;272:H2919-31.

[71] Yeung VT, Ho SK, Nicholls MG, Cockram CS. Binding of CNP-22 and CNP-5 to cultured mouse astrocytes and effects on cyclic GMP. Peptides 1996; $17: 101-6$

[72] Suga S, Nakao K, Itoh H, Komatsu Y, Ogawa Y, Hama N, et al. Endothelial production of C-type natriuretic peptide and its marked augmentation by transforming growth factor-beta. Possible existence of "vascular natriuretic peptide system". J Clin Invest 1992;90:1145-9.

[73] Suga S, Itoh H, Komatsu Y, Ogawa Y, Hama N, Yoshimasa T, et al. Cytokineinduced C-type natriuretic peptide (CNP) secretion from vascular endothelial cells - evidence for CNP as a novel autocrine/paracrine regulator from endothelial cells. Endocrinology 1993;133:3038-41.

[74] Chun TH, Itoh H, Ogawa Y, Tamura N, Takaya K, Igaki T, et al. Shear stress augments expression of C-type natriuretic peptide and adrenomedullin. Hypertension 1997;29:1296-302.

[75] Hunt PJ, Richards AM, Espiner EA, Nicholls MG, Yandle TG. Bioactivity and metabolism of C-type natriuretic peptide in normal man. J Clin Endocrinol Metab 1994;78:1428-35.

[76] Palmer SC, Prikett TCR, Espiner EA, Yandle TG, Richards AM. Regional release and clearance of C-type natriuretic peptides in the human circulation and relation to cardiac function. Hypertension 2009;54:612-8.

[77] Del Ry S, Cabiati M, Stefano T, Catapano G, Caselli C, Prescimone T, et al. Comparison of NT-proCNP and CNP plasma levels in heart failure, diabetes and cirrhosis patients. Regul Pept 2011;166:15-20.

[78] Prickett TCR, Yandle TG, Nicholls MG, Espiner EA, Richards AM. Identification of amino-terminal pro-C-type natriuretic peptide in human plasma. Biochem Biophys Res Commun 2001;286:513-7.

[79] Wei CM, Heublein DM, Perella MA, Lerman A, Rodeheffer RJ, McGregor CG, et al. Natriuretic peptide system in human heart failure. Circulation 1993;88:1004-9.

[80] Del Ry S, Maltinti M, Emdin M, Passino C, Catapano G, Giannessi D. Radioimmunoassay for plasma C-type natriuretic peptide determination: a methodological evaluation. Clin Chem Lab Med 2005;43:641-5.

[81] Del Ry S, Passino C, Maltinti M, Emdin M, Giannessi D. C-type natriuretic peptide plasma levels increase in patients with congestive heart failure as a function of clinical severity. Eur J Heart Fail 2005;7:1145-8.
[82] Del Ry S, Giannessi D, Maltinti M, Prontera C, Iervasi A, Colotti C, et al. Increased levels of C-type natriuretic peptide in patients with idiopathic left ventricular dysfunction. Peptides 2007;28:1068-73.

[83] Del Ry S, Maltinti M, Cabiati M, Emdin M, Giannessi D, Morales MA. C-type natriuretic peptide and its relation to non invasive indices of left ventricular function in patients with chronic heart failure. Peptides 2008;29:79-82.

[84] Kalra PR, Clague JR, Bolger AP, Anker SD, Poole-Wilson PA, Struthers AD, et al. Myocardial production of C-type natriuretic peptide in chronic heart failure. Circulation 2003;107:571-3.

[85] Del Ry S, Maltinti M, Piacenti M, Passino C, Emdin M, Giannessi D. Cardiac production of C-type natriuretic peptide in heart failure. J Cardiovasc Med 2006; 7:397-9.

[86] Del Ry S, Cabiati M, Lionetti V, Emdin M, Recchia FA, Giannessi D. Expression of C-type natriuretic peptide and of its receptor NPR-B in normal and failing heart. Peptides 2008;29:2208-15.

[87] Del Ry S, Cabiati M, Lionetti V, Simioniuc A, Caselli C, Prescimone T, et al. Asymmetrical myocardial expression of natriuretic peptides in pacing-induced heart failure. Peptides 2009;30:1710-3.

[88] Del Ry S, Cabiati M, Lionetti V, Giannessi D. NPR-B, the C-type natriuretic peptide specific receptor, is the predominant biological receptor in mouse and pig myocardical tissue. Minerva Endocrinol 2010;35:37-46.

[89] Cabiati M, Sabatino L, Caruso R, Caselli C, Prescimone T, Giannessi D, et al. Gene expression of C-type natriuretic peptide and of its specific receptor NPR-B in human leukocytes of healthy and heart failure subjects. Peptides 2012;37:240-6.

[90] Cabiati M, Sabatino L, Caruso R, Verde A, Caselli C, Prescimone T, et al. C-type natriuretic peptide transcriptomic profiling increases in human leukocytes of patients with chronic heart failure as a function of clinical severity. Peptides 2013;47C:110-4

[91] Nazario B, Hu R, Pedram A, Bruce P, Levin ER. Atrial and brain natriuretic peptides stimulate the production and secretion of $C$-type natriuretic peptide from bovine aortic endothelial cells. J Clin Invest 1995;95:1151-7.

[92] Beaulieu P, Cardinal R, Page P, Francoeur F, Tremblay J, Lambert C. Positive chronotropic an inotropic effects of C-type natriuretic peptide in dogs. Am J Physiol 1997;273:H1933-40.

[93] Qvigstad E, Moltzau LR, Aronsen JM, Nguyen CH, Hougen K, Sjaastad I, et al. Natriuretic peptides increase beta1-adrenoceptor signaling in failing hearts through phosphodiesterase 3 inhibition. Cardiovasc Res 2010;85:763-72.

[94] Wang Y, de Waard MC, Sterner-Kock A, Stepan H, Schultheiss HP, Duncker DJ, et al. Cardiomyocyte-restricted over-expression of C-type natriuretic peptide prevents cardiac hypertrophy induced by myocardial infarction in mice. Eur J Heart Fail 2007;9:548-57.

[95] Del Ry S, Cabiati M, Martino A, Cavallini C, Caselli C, Aquaro GD et al. High concentration of C-type natriuretic peptide promotes VEGFdependent vas-culogenesis in the remodeled region of infarcted swine heart with preserved left ventricular ejection fraction. Int J Cardiol 2013 http://dx.doi.org/10.1016/j.ijcard.2013.03.015, pii: S0167-5273(13)00434-8 (Epub ahead of print).

[96] Soeki T, Kishimoto I, Okumura H, Tokudome T, Horio T, Mori K, et al. Ctype natriuretic peptide, a novel antifibrotic and antihypertrophic agent, prevents cardiac remodeling after myocardial infarction. J Am Coll Cardiol 2005;45:608-16.

[97] Mattingly MT, Brandt RR, Heublein DM, Wei C, Nir A, Burnett JC. Presence of C-type natriuretic peptide in human kidney and urine. Kidney Int 1994:46:744-7.

[98] Topol EJ. The lost decade of nesiritide. N Engl J Med 2011;365:81-2.

[99] Ahmad T, Felker GM. Subcutaneous natriuretic peptide for treatment of heart failure. A dying therapy reborn? J Am Coll Cardiol 2012;60:2313-5.

[100] Vaduganathan M, Greene SJ, Ambrosy AP, Gheorghiade M, Butler J. The disconnect between phase II and phase III trials of dugs for heart failure. Nat Rev Cradiol 2013;10:85

[101] Mangiafico S, Costello-Boerrigter LC, Andersen IA, Cataliotti A, Burnett Jr JC. Neutral endopeptidase inhibition and the natriuretic peptide system: an evolving strategy in cardiovascular therapeutics. Eur Heart J 2013;34:886-93.

[102] Chen HH, Glockner JF, Schirger JA, Cataliotti A, Redfield MM, Burnett Jr JC. Novel protein therapeutics for systolic heart failure: chronic subcutaneous B-type natriuretic peptide. J Am Coll Cardiol 2012;60:2305-12.

[103] Hayek S, Nemer M. Cardiac natriuretic peptides: from basic discovery to clinical practice. Cardiovasc Ther 2011;29:362-76.

[104] Gassanov N, Biesenbach E, Caglayan E, Nia A, Fuhr U, Er F. Natriuretic peptides in therapy for decompensated heart failure. Eur J Clin Pharmacol 2012;68:223-30.

[105] Zakeri R, Burnett JC. Designer natriuretic peptides: a vision for the future of heart failure therapeutics. Can J Physiol Pharmacol 2011;89:593-601.

[106] Rose RA. CD-NP, a chimeric natriuretic peptide for the treatment of heart failure. Curr Opin Invest Drugs 2010;11:349-56.

[107] Lee CY, Chen HH, Lisy O, Swan S, Cannon C, Lieu HD, et al. Pharmacodynamics of a novel designer natriuretic peptide, CD-NP, in a first-in-human clinical trial in healthy subjects. J Clin Pharmacol 2009;49:668-73. 